\title{
In vitro inhibitory activity of Achyranthes aspera L. seed against some test bacteria
}

\author{
Dash B. K. , Sen M. K., Alam M. K. \\ Department of Biotechnology and Genetic Engineering, Faculty of Applied Science and Technology, Islamic University, Kushtia-7003, \\ Bangladesh
}

\section{Email address:}

biplab.iu@gmail.com (Dash B. K.)

\section{To cite this article:}

Dash B. K., Sen M. K., Alam M. K.. In Vitro Inhibitory Activity of Achyranthes aspera L. Seed against Some Test Bacteria. American Journal of Life Sciences. Vol. 1, No. 3, 2013, pp. 113-116. doi: 10.11648/j.ajls.20130103.16

\begin{abstract}
The inhibitory activity of seed extracts of Achyranthes aspera, a widely used folk medicinal plant in Bangladesh, was examined using methanol, acetone, ethyl acetate and petroleum sprit as solvents against five test bacteria by disc diffusion method. Methanol extract was found to reveal significant inhibitory activity against the pathogenic $B$. subtilis, E. coli and K. pneumoniae. Only the methanol and ethyl acetate extracts were effective against all bacteria and the best activity was found against $B$. subtilis in terms of zone of clearance. The best minimum inhibitory concentration value was found by methanol extract against $B$. subtilis. The present study suggests that the methanol extract of seed of this plant could be a possible source of obtaining new and effective herbal medicines to treat infections; hence, it justified the ethnic use.
\end{abstract}

Keywords: Achyranthes Aspera, Inhibitory Activity, Medicinal Plant

\section{Introduction}

Medicinal plants have been playing significant roles since ancient traditional systems of medication in many countries. They are rich source of bioactive compounds and thus serve as important raw materials for drug production [1]. During the last two decades, the development of drug resistance as well as the appearance of undesirable side effects of certain antibiotics [2] due to the indiscriminate use of commercial antimicrobial drugs commonly used in the treatment of infectious disease [3], has led to the search of new antimicrobial agents mainly among plant extracts with the goal to discover new chemical structures, which overcome the above disadvantages [4]. This situation forced scientists to develop alternative antimicrobial drugs for the treatment of infectious diseases from medicinal plants [5]. The antimicrobial activities of plant extracts may reside in a variety of different secondary metabolites, including aldehyde and phenolic compounds [6]. A number of scientific investigations have highlighted the importance and the contribution of so many plant families namely Asteraceae, Liliaceae, Apocynaceae, Solanaceae, Caesalpinaceae, Rutaceae, Piperaceae, Sapotaceae, Amaranthaceae etc. used as medicinal plants $[1,7]$. Hence the sensitivity study of bacterial strains to the plant
Achyranthes aspera was evaluated.

A. aspera Linn. belongs to the family Amaranthaceae, is an annual, stiff erect herb, and found commonly as a weed throughout Bangladesh. The plant is used in indigenous system of medicine as emenagogue, antiarthritic, antifertility, laxative, ecbolic, abentifacient, anti-helminthic, aphrodisiac, antiviral, anti-plasmodic, antihypertensive, anticoagulant, diuretic and anti-tumor [8-9]. It is also useful to treat cough, renal dropsy, fistula, scrofula, skin rash, nasal, infection, chronic malaria, impotence, fever, asthma, piles and snake bites [10]. This plant is astringent, digestive, diuretic, laxative, purgative and stomachic. The juice of the plant is used in the treatment of boils, diarrhea, dysentery, hemorrhoids, rheumatic pains, itches and skin eruptions [11]. It is reported to contain alkaloids, flavonoids, saponins, steroids and terpenoids. Flavonoids have shown to prevent or slows the development of some cancers [12] and mostly act as an anti-oxidant and anti-inflammatory agents. Saponins have long been known to have strong biological activity. The water soluble alkaloid achyranthine isolated from $A$. aspera possess anti-inflammatory activity [13]. Many in vitro antimicrobial studies of different extracts of roots, leaves and stems of $A$. aspera has been carried out but none of them used seed.

The present study was carried out to test the antibacterial 
efficacy of the seed extract of $A$. aspera.

\section{Materials and Methods}

\subsection{Plant Material}

Healthy, disease free, mature Apang (A. aspera) plant was collected directly from nature (university region of Kushtia, Bangladesh) on September, 2010. The herb was then botanically identified and characterized by a taxonomist. After cleaning the waste materials with water, the plant was air dried. The seeds were then collected and the name of the plant, time, place, and date of collection were recorded.

\subsection{Extract Preparation}

Collected $A$. aspera seeds were cleaned with deionized water and dried in shade and pulverized into fine powdered substance by a grinding machine. Each $10 \mathrm{gm}$ of powdered seed was weighted with the electric balance and transferred into five separate $100 \mathrm{ml}$ conical flasks. Then each $40 \mathrm{ml}$ of methanol, ethyl acetate, acetone and petroleum sprit was added in the flasks respectively. The conical flasks were closed by foil paper and placed on a shaker at $37^{\circ} \mathrm{C}$ temperature for $24 \mathrm{~h}$. The crude extracts were then filtered by passing the extracts through Whatmann No. 1 filter paper (UK) and concentrated under vacuum at $40^{\circ} \mathrm{C}$ by using a rotary evaporator. The residual extracts were stored in refrigerator at $4^{\circ} \mathrm{C}$ in small and sterile plastic bottles.

\subsection{Test Bacteria}

Antibacterial activity of $A$. aspera seed extracts was investigated against three gram-negative (Xanthomonas campestris, Escherichia coli and Klebsiella pneumoniae) and two gram positive (Bacillus subtilis and Sarcina lutea) bacterial isolates, obtained from the Microbiology Laboratory, Department of Biotechnology and Genetic Engineering, Islamic University, Kushtia, Bangladesh. The test microorganisms were cultured on nutrient agar (Oxoid, UK) at $37^{\circ} \mathrm{C}$ for $24 \mathrm{~h}$. The cultures were sub-cultured regularly (every 30 days) and stored at $4^{\circ} \mathrm{C}$.

\subsection{Inoculum Preparation}

Ten (10) $\mathrm{ml}$ of distilled water containing screw capped tube was added with pure colony of freshly cultured bacteria followed by vortexing. The OD (optical density) was measured with the colorimeter and microbial population was confirmed to be within in $10^{7} \mathrm{ml}^{-1}$ to $10^{8}$ $\mathrm{ml}^{-1}$ and then plated out as inoculums [14].

\subsection{Antimicrobial Bioassay}

The in vitro antimicrobial activities of the test samples were carried out by disc diffusion method [15-16]. Dried and sterilized filter paper discs $(6 \mathrm{~mm}$ diameter $)$ were impregnated with test substances (extracts) dissolved in solvents and the residual solvents were completely evaporated. Discs containing the test materials were placed on nutrient agar medium uniformly seeded with the test

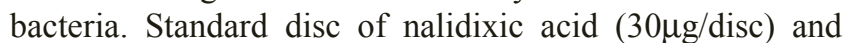
blank discs (impregnated with solvents followed by evaporation) were used as positive and negative control, respectively. These plates were then kept at low temperature $\left(4^{\circ} \mathrm{C}\right)$ for $24 \mathrm{~h}$ to allow maximum diffusion of test samples and then incubated at $37^{\circ} \mathrm{C}$ for $24 \mathrm{~h}$ to allow maximum growth of the bacteria. The antibacterial activity of the test agents was determined by measuring the diameter of zone of inhibition in millimeter. Minimum inhibitory concentration (MIC) values of the extracts showing significant results (methanol and ethyl acetate extracts) were determined in the present study following the serial dilution technique [17].

\subsection{Statistical Evolution}

The experiments were repeated three times and the results were determined as an average value. Readings were made visually. The MIC endpoint was considered as the lowest drug concentration of antibacterial agent inhibiting the total growth.

\section{Results and Discussion}

Higher zone of inhibition against the bacterial pathogens exhibited by the extracts is of great significance in the health care delivery system, since it could be used as an alternative to orthodox antibiotics in the treatment of infections, especially as they frequently develop resistance to known antibiotics [10]. Among all tested extracts in the present study, methanol and ethyl acetate extracts were found to be most sensitive than corresponding organic extracts (Table 1). Methanol extract revealed comparatively better results found to have maximum zone of inhibition against $B$. subtilis $(12 \mathrm{~mm})$ and it was significantly susceptible against $K$. pneumoniae $(11 \mathrm{~mm})$. Earlier study reported similar result revealed with methanol extract [18]. The alcoholic extracts have been reported to have wound healing and antioxidant activities [19]. The lowest MIC value was $256 \mu^{-1} \mathrm{gml}^{-1}$ against $B$. subtilis (Table 2) showed by methanol extract. Methanolic leaf extract of $A$. aspera reported as potent inhibitor of Gram positive Staphlyococcus aureus with a minimal inhibitory concentration of $5000 \mu \mathrm{lml}^{-1}$ [11]. Our study possessed relatively good results. The acetone extract was most effective against $B$. subtilis $(11 \mathrm{~mm})$ whereas inactive against $E$. coli. Ethyl acetate extract was found to be most active against both $B$. subtilis and E. coli $(9 \mathrm{~mm})$. The petroleum sprit extract showed highest activity against $E$. coli $(9 \mathrm{~mm})$ but inactive against $K$. pneumoniae. It has been found to support these findings likely [20]. Other studies on antimicrobial screening of different parts of $A$. aspera revealed its poor antibacterial activity and broad spectrum antifungal activity [21-22]. Negative controls (disc containing only solvents) showed no zone against any test 
bacteria. Thus no solvent process any antibacterial activity. Positive control (nalidixic acid) produce greater zone of

inhibitions against all the test bacteria (Table 1).

Table 1. Antibacterial activity of different extract of A. aspera seed

\begin{tabular}{cccccc}
\hline Test Bacteria & \multicolumn{5}{c}{ Diameter of Zone of Inhibition (mm) } \\
Methanol & Acetone & Ethyl acetate & Petroleum sprit & Nalidixic acid (30 $\boldsymbol{\mu g})$ \\
\hline B. subtilis & 12 & 11 & 9 & 7.5 & 27 \\
S. lutea & 7 & 8 & 7 & 7 & 24 \\
X. campestris & 8.5 & 7 & 7 & 7 & 27 \\
E. coli & 10.5 & 0 & 9 & 9 & 28 \\
K. pneumoniae & 11 & 7.5 & 8 & 0 & 29 \\
\hline
\end{tabular}

Table 2. MIC values of methanol and ethyl acetate extracts of A. aspera seed

\begin{tabular}{|c|c|c|c|c|c|c|c|c|c|c|c|c|c|c|c|c|c|c|c|c|c|c|c|c|}
\hline \multirow{2}{*}{ Test Bacteria } & \multicolumn{14}{|c|}{ Methanol extract $\left(\mu \mathrm{gmm}^{-1}\right)$} & \multicolumn{10}{|c|}{ Ethyl acetate extract $\left(\mu \mathrm{gml}^{-1}\right)$} \\
\hline & 4096 & 2048 & 1024 & 512 & 256 & 128 & 64 & 32 & 16 & 84 & 42 & $\mathbf{0}$ & 4096 & 2048 & 1024 & 512 & 256 & 128 & 64 & 32 & 16 & 8 & 4 & 20 \\
\hline B. subtilis & - & - & - & - & - & + & + & + & + & ++ & ++ & + & - & - & + & + & + & + & + & + & + & + & + & ++ \\
\hline S. lutea & - & - & + & + & + & + & + & + & + & ++ & ++ & + & - & + & + & + & + & + & + & + & + & + & + & ++ \\
\hline X. campestris & - & - & + & + & + & + & + & + & + & ++ & ++ & + & - & + & + & + & + & + & + & + & + & + & +- & ++ \\
\hline E. coli & - & - & - & + & + & + & + & + & + & ++ & ++ & + & - & - & + & + & + & + & + & + & + & + & + & ++ \\
\hline K. pneumoniae & - & - & - & + & + & + & + & + & + & ++ & ++ & + & - & + & + & + & + & + & + & + & + & + & + & ++ \\
\hline
\end{tabular}

‘+'= No zone formation; '-'= Formation of inhibition zone

\section{Conclusion}

The seed extracts of A. aspera seed were found to be effective against test bacteria, three of which are pathogenic for human. This study paves the way for further attention and research to identify the active compounds responsible for the plant biological activity, to characterize the active compounds and to elucidate the exact mechanism of action by which they exert their antibacterial effects.

\section{Conflict of Interest Statement}

The authors declare that they have no conflict of interest.

\section{Acknowledgement}

The authors wish to thank the Department of Biotechnology and Genetic Engineering, Islamic University, Kushtia, Bangladesh for providing laboratory facilities.

\section{References}

[1] Tullanithi KM, Sharmila B and Gnanendra TS. Preliminary phytochemical analysis and antimicrobial activity of
Achyranthes aspera Linn. Int. J. Biol. Technol. 2010; 1(3): 35-38.

[2] Okemo PO, Bais HP and Vivanco JM. In vitro activities of Maesa lanceolata extracts against fungal plant pathogens. Fitoterapia. 2003; 74: 312-316.

[3] Lakshmi NPV, Kishore KK, Mohan KC, Gunesh G and Narasimha RM. Antimicrobial activity of Achyranthes aspera. Biosci. Biotechnol. Res. Asia. 2006; 3: 1-2.

[4] Bouamama H, Noel T, Villard J, Benharref A and Jana M. Antimicrobial activities of the leaf extract of two Moroccan Cistus L species. J. Ethnopharmacol. 2006; 104: 104-107.

[5] Valsaraj R, Pushpangadan P, Smitt UW, Andersen A and Nyman U. Antimicrobial screening of selected medicinal plants from India. J. Ethnopharmacol. 1997; 58: 75-83.

[6] Lai PK and Roy J. Antimicrobial and chemopreventive properties of herbs and spices. Cur. Med. Chem. 2004; 11: $1451-1460$.

[7] Watt JM and Breyer-Brandwijk MG. Medicinal and Poisonous Plants of Southern and Eastern Africa, $2^{\text {nd }}$ edition. E \& S Livingstone. 1962; p989-1008.

[8] Anonymous. The Wealth of India, Raw Materials. New Delhi: Publication and Information Directorate, Center for Scientific and Industrial Research (CSIR). 1985; p57.

[9] Ratra PS and Misra KC. Seasonal variation in chemical composition of $A$. aspera and A. bidentata. Indian Forester. 1970; 96: 372-375. 
[10] Singleton P. Bacteria in Biology, Biotechnology and Medicine. $4^{\text {th }}$ edition. New York, John Wiley and Sons Ltd. 1999.

[11] Londonkar R, Reddy CV and Kumar AK. Potential antibacterial and antifungal activity of Achyranthes aspera L. Recent Res. Sci. Technol. 2011; 3(4): 53-57.

[12] Narayana RK, Reddy SM, Chaluvadi MR and Krishna DR. Bioflavanoids: classification, pharmacological, biochemical effects and therapeutic potentials. Indian J. Pharmacol. $2001 ; 33: 2-16$

[13] Gokhale AB, Damre AS, Kulkami KR and Saraf MN. Preliminary evaluation of anti-inflammatory and antiarthritic activity of S. lappa, A. speciosa and A. aspera. J. Phytomed. 2002; 9(5): 433-437.

[14] Seher G, Dilek Turgut-Balik and Nazmi G. Antimicrobial activities and some fatty acids of Turmeric, Ginger root and Linseed used in treatment of infectious diseases. World J. Agri. Sci. 2006; 2(4): 439-442.

[15] Bauer AW, Kirby WM., Sherris JC and Turck M. Antibiotic susceptibility testing by a standardized single disc method. American J. Clin. Pathol. 1966; 45: 493-496.
[16] NCCLS. Performance standards for antimicrobial disk susceptibility tests: Approval standard M2-A7 $7^{\text {th }}$ edition. Pennsylvania: Clinical and Laboratory Standards Institute. 2000.

[17] Reiner R. Antibiotica: An Introduction. F. Hoffman (Ed.). La Roche and Co. Ltd. Switzerland. 1982; p23-30.

[18] Ashokkumar P, Rajkumar and Kanimozhi. Phytochemical screening and antimicrobial activity from five Indian medicinal plants against human pathogens. Middle-East J. Sci. Res. 2010; 5(6): 477-482.

[19] Varuna KM, Khan MU and Sharma PK. Review on Achyranthes aspera. J. Pharm. Res. 2010; 3(4): 714-717.

[20] Beaulah AG, Sadiq MA and Santhi JR. Antioxidant and antibacterial activity of Achyranthes aspera: An in vitro study. Der Pharma Chemica. 2011; 3(5): 255-262.

[21] Alam MT, Karim MM and Khan SN. Antibacterial activity of different organic extracts of Achyranthes aspera and Cassia alata. J. Sci. Res. 2009; 1: 393-398.

[22] Elumalai EK, Chandrasekaran N, Thirumalai T, Sivakumar C, Therasa SV and David E. Achyranthes aspera leaf extracts inhibited fungal growth. Int. J. Pharm. Tech. Res. 2009; 1(4): 1576-1579. 